\title{
TRADITIONAL USES OF MEDICINAL PLANTS IN MAHARASHTRA VIDHARBH REGION
}

\author{
Matte R. S. \\ Lokmanya Tilak Mahavidyalya Wani, Yavatmal (M.S) India \\ Email: ravindramattewani@gmail.com
}

\begin{abstract}
The Vidharbha have a great wealth of medicinal plants and traditional medicinal knowledge. Medicinal plants have played an important role of primary health care system among the local people of Vidharbha region. The present paper is a study of the traditional knowledge of medicinal plants and its use by local people of Vidharbha Region. Due to its unique geographical location and different climatic condition, it has rich biodiversity and variety of plant species. Medicinal plants are the principal health care resources among the most of people in India. Local people of this region are basically depends upon medicinal plants for their primary health care system. Their primary cure of diseases is based upon deep observation of nature and their understanding of traditional knowledge of medical practices. Local people in this region, especially tribal people and women heavily use these traditionally available medicinal plants for health and believe that these are easily available, less expensive and have no side effects as compare to modern medicine. The plants used for medicinal purposes in the primary health traditions are slowly becoming extinct due to development activities, population explosion, impact of tourism, deforestation and many more. The present paper focuses about the indigenous knowledge of different medicinal plants used in the Vidharbha region. Ethnomedicinal uses of 111 medicinal plant species along with botanical name, part used and mode of treatment are given in this paper.
\end{abstract}

Keywords: Medicinal Plants, Traditional Knowledge, Deforestation, Ethnomedicinal

\section{Introduction:}

The Vidharbha have a great wealth of medicinal plants and traditional medicinal knowledge. Medicinal plants have played an important role of primary health care system among the local people of Vidharbha region. As the local people are settled far from urban area, they cannot take modern health care facilities so they are totally dependent on traditional medicinal practices for their primary health care. Out of 15,000 species of flowering plants found in India, about $17 \%$ have their medicinal. Local people of this region are partially or completely dependent on forest resources for medicine, food, and fuel and medicinal species are steadily diminishing due to anthropogenic activities ( Chhetri DR). Vidharbha has a rich variety of herbs, medicinal and aromatic plant species. The ancient documentation of 67 medicinal plants in Hindu culture is found in the "Rigveda," which is thought to have been written between 4,500 and 1,600 BC( Malla $\mathrm{SB})$. Collection and trade of medicinal plants to India is a historical fact. The trade of non-timber jungle products is mentioned in the 3,000 years old Ramayan (Edwards DM). Similarly the Vidharbha provides outstanding information about plants and their medicinal properties. The Charak and the Sushrut Samhitas were written between 700-200 BC, and contain accounts of the finding of medicinal plants (Pandey HP). India"s natural forests are home to about 8000 medicinal plants that form the primary source of health care for $60-80 \%$ of the countryes population, specially the rural people, tribal community and poor people. About $80 \%$ of traditional medicines used for principal healthcare are derived from plants (Fransworth). During the last few decades, there has been an increasing interest in the study of medicinal plants and their traditional use in different parts of the glob . Documenting indigenous knowledge through ethnomedicinal studies is significant for the management and utilization of biological resources. The World Health Organization (WHO) suggested that as many as $80 \%$ of the worlds people depend on traditional medicine for their primary healthcare needs. There are significant economic benefits in the development of indigenous medicines and in the use of medicinal plants for the cure of various diseases (Azaizeh HS).

\section{Geography of Vidharbha:}

Vidhharbha is the eastern region of the Indian state of Maharashtra, comprising 
Nagpur Division and Amravati Division. Its former name is Berar (Varhad in Marathi). It occupies $31.6 \%$ of total area and holds $21.3 \%$ of total population of Maharashtra. It borders the state of Madhya Pradesh to the north, Chhattisgarh to the east, Telangana to the south and Marathwadha and Khandesh region of Maharashtra to the west. Situated in central India, Vidarbha has its own rich cultural and historical background district from rest of Maharashtra. The largest city in Vidharbha is Nagpur. A majority of Vidharbhian speak Hindi, Varhadi and Zadi dialect of Marathi. Several wildlife sanctuaries, national parks and Project Tiger reserves have been created in Maharashtra, with the aim of conserving the rich bio-diversity of the region.

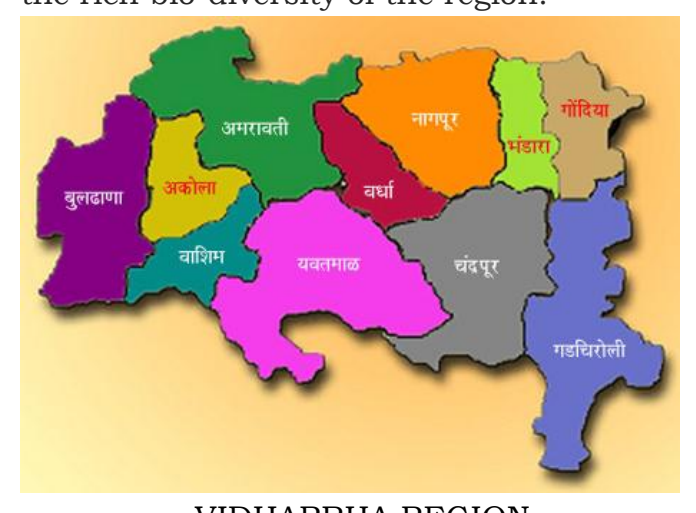

\section{VIDHARBHA REGION}

\section{Methodology:}

The data was collected through secondary sources mainly from the website of Government of Maharashtra, State Mediciane Plant Board of Maharashtra and Forest department of Maharashtra. References from research papers, books, articles and news paper were taken for interpretation of data.

\begin{tabular}{|c|c|c|c|c|c|}
\hline $\begin{array}{l}\text { S. } \\
\text { No. }\end{array}$ & $\begin{array}{l}\text { Botanical } \\
\text { Name }\end{array}$ & Local Name & $\begin{array}{l}\text { Parts } \\
\text { used }\end{array}$ & Uses & $\begin{array}{lr}\text { Mode of } \\
\text { Treatment }\end{array}$ \\
\hline 1 & $\begin{array}{l}\text { Justicia } \\
\text { adhatoda L. }\end{array}$ & Adulsa & Leaves & cough & $\begin{array}{l}\text { Leaves } \\
\text { extract }\end{array}$ \\
\hline 2 & $\begin{array}{l}\text { Barleria } \\
\text { prionitis L. }\end{array}$ & $\begin{array}{l}\text { Kate } \\
\text { Korante }\end{array}$ & $\begin{array}{l}\text { Whole } \\
\text { Plant }\end{array}$ & Fever & Decoction \\
\hline 3 & $\begin{array}{l}\text { Celosia } \\
\text { argentea L. }\end{array}$ & Kurdu & Leaves & $\begin{array}{l}\text { Kidney } \\
\text { Stone }\end{array}$ & $\begin{array}{l}\text { Leaves } \\
\text { extract }\end{array}$ \\
\hline 4 & $\begin{array}{l}\text { Annona } \\
\text { squamosa L. }\end{array}$ & Sitafal & Leaves & Leaves & Powder \\
\hline 5 & $\begin{array}{l}\text { Alstonia } \\
\text { scholaris (L.) }\end{array}$ & Saptaparni & Bark & Fever & Powder \\
\hline 6 & \begin{tabular}{|l|} 
Tridax \\
procumbens \\
L.
\end{tabular} & Kamarmodi & Leaves & Wound & $\begin{array}{l}\text { Leaves } \\
\text { extract }\end{array}$ \\
\hline 7 & $\begin{array}{l}\text { Bombax ceiba } \\
\text { L. }\end{array}$ & Katsawar & Bark & Wound & Powder \\
\hline 8 & Opuntia & Nagfuni & Fruit & Cough & Powder \\
\hline
\end{tabular}

\begin{tabular}{|c|c|c|c|c|c|}
\hline & elatior Mill. & & & & \\
\hline 9 & $\begin{array}{l}\text { Cassia fistula } \\
\text { L. }\end{array}$ & Bahawa & Bark & Cancer & Powder \\
\hline 10 & $\begin{array}{l}\text { Cassia tora } \\
\text { L. }\end{array}$ & Tarota & Root & Snake bite & Powder \\
\hline 11 & $\begin{array}{l}\text { Tamarindus } \\
\text { indica } \mathrm{L} \text {. }\end{array}$ & Chinha & Leaves & Pain & $\begin{array}{l}\text { Leaves } \\
\text { extract }\end{array}$ \\
\hline 12 & $\begin{array}{l}\text { Canna indica } \\
\text { L. }\end{array}$ & Karadali & Rhizome & Fever & Powder \\
\hline 13 & $\begin{array}{l}\text { Capparis } \\
\text { zeylanica } \mathrm{L} .\end{array}$ & Waghati & Bark & Dropsy & Powder \\
\hline 14 & $\begin{array}{l}\text { Terminalia } \\
\text { cuneata } \text { Roth }\end{array}$ & Arjuna & Bark & \begin{tabular}{|l} 
Heart \\
diseases
\end{tabular} & Powder \\
\hline 15 & $\begin{array}{l}\text { Cucumis } \\
\text { sativus L. }\end{array}$ & Kakadi & Fruit & Digestive & Fruit \\
\hline 16 & $\begin{array}{l}\text { Cyperus } \\
\text { rotundus L. }\end{array}$ & Nagarmotha & Seeds & fever & Powder \\
\hline 17 & $\begin{array}{l}\text { Ricinus } \\
\text { communis L. }\end{array}$ & Yerandi & Leaves & Lactation & $\begin{array}{l}\text { Leaves } \\
\text { syrap }\end{array}$ \\
\hline 18 & \begin{tabular}{|l|} 
Abrus \\
precatorius L.
\end{tabular} & Gunja & Leaves & Swelling & $\begin{array}{l}\text { Leaves } \\
\text { extract }\end{array}$ \\
\hline 19 & $\begin{array}{l}\text { Crotalaria } \\
\text { juncea L. }\end{array}$ & Tag & Root & Epitaxis & Powder \\
\hline 20 & $\begin{array}{l}\text { Vigna trilobus } \\
\text { (L.) Verdc. }\end{array}$ & Ran mung & Leaves & \begin{tabular}{|l} 
Eye \\
diseases
\end{tabular} & $\begin{array}{l}\text { Leaves } \\
\text { extract }\end{array}$ \\
\hline 21 & $\begin{array}{l}\text { Mentha } \\
\text { piperita L. }\end{array}$ & Pudina & $\begin{array}{l}\text { Whole } \\
\text { plant }\end{array}$ & Fever & Decocction \\
\hline 22 & \begin{tabular}{|l|} 
Ocimum \\
tenuiflorum L. \\
\end{tabular} & Tulas & Leaves & cough & Decocction \\
\hline 23 & $\begin{array}{l}\text { Allium cepa } \\
\text { L. }\end{array}$ & Kanda & Bulp & Pain killer & Pest \\
\hline 24 & $\begin{array}{l}\text { Allium } \\
\text { sativum L. }\end{array}$ & Lahsun & Fruit & Headache & Pest \\
\hline 25 & $\begin{array}{l}\text { Gloriosa } \\
\text { superba } \mathrm{L} .\end{array}$ & Karkari & Root & Inflamation & Powder \\
\hline 26 & $\begin{array}{l}\text { Lawsonia } \\
\text { inermis L. }\end{array}$ & Mehandi & Leaves & Rhumatism & Pest \\
\hline 27 & $\begin{array}{l}\text { Urena lobata } \\
\text { L. }\end{array}$ & Ran bhendi & Root & Asthama & Powder \\
\hline 28 & $\begin{array}{l}\text { Gossypium } \\
\text { hirsutum L. }\end{array}$ & Kapus & Fruit & $\begin{array}{l}\text { Skin } \\
\text { diseases }\end{array}$ & Pest \\
\hline 29 & $\begin{array}{l}\text { Hibiscus } \\
\text { cannabinus } \\
\text { L. }\end{array}$ & Ambadi & Leaves & Cough & $\begin{array}{l}\text { Leaves } \\
\text { extract }\end{array}$ \\
\hline 30 & $\begin{array}{l}\text { Sida } \\
\text { cordifolia L. }\end{array}$ & Bala & $\begin{array}{l}\text { Whole } \\
\text { plant }\end{array}$ & Tonic & Decocction \\
\hline 31 & $\begin{array}{l}\text { Martynia } \\
\text { annua L. }\end{array}$ & Wagnakhi & Fruit & Snake bite & Pest \\
\hline 32 & $\begin{array}{l}\text { Melia } \\
\text { azedarach L. }\end{array}$ & Bakani & Leaves & Histyria & Decocction \\
\hline 33 & $\begin{array}{l}\text { Mimosa } \\
\text { hamata } \\
\text { Willd. }\end{array}$ & Chilati & Root & Rhumatism & Powder \\
\hline 34 & $\begin{array}{l}\text { Mimosa } \\
\text { pudica L. }\end{array}$ & Lajalu & Leaves & Dysentry & Decocction \\
\hline 35 & \begin{tabular}{|l|} 
Ficus \\
benghalensis \\
L.
\end{tabular} & Wad & Root & Gonorrhea & Powder \\
\hline 36 & $\begin{array}{l}\text { Ficus } \\
\text { racemosa L. }\end{array}$ & Umber & Fruit & U.T.I & Powder \\
\hline 37 & \begin{tabular}{|l} 
Ficus \\
religiosa L.
\end{tabular} & Pimpal & Leaves & $\begin{array}{l}\text { Heart } \\
\text { diseases }\end{array}$ & Decocction \\
\hline 38 & \begin{tabular}{|l|} 
Moringa \\
oleifera Lam.
\end{tabular} & Shevaga & Seeds & Headache & Pest \\
\hline 39 & $\begin{array}{l}\text { Embelia ribes } \\
\text { Burm. f. }\end{array}$ & Vavading & Bark & \begin{tabular}{|l} 
Lung \\
disease
\end{tabular} & Powder \\
\hline 40 & $\begin{array}{l}\text { Careya } \\
\text { arborea } \\
\text { Roxb. }\end{array}$ & Kumbhi & Bark & Cough & Powder \\
\hline 41 & $\begin{array}{l}\text { Psidium } \\
\text { guajava L.. }\end{array}$ & Peru & Fruit & $\begin{array}{l}\text { Sperm } \\
\text { count }\end{array}$ & Powder \\
\hline 42 & $\begin{array}{l}\text { Jasminum } \\
\text { officinale L. }\end{array}$ & Chameli & Leaves & Cough & Decocction \\
\hline 43 & $\begin{array}{l}\text { Nyctanthes } \\
\text { arbor-tristis } \\
\text { L. }\end{array}$ & Parijat & Bark & Cough & Powder \\
\hline 44 & Argemone & Piwala & Seeds & Skin & Pest \\
\hline
\end{tabular}




\begin{tabular}{|c|c|c|c|c|c|}
\hline & mexicana L. & Dhotra & & diseases & \\
\hline 45 & $\begin{array}{l}\text { Sesamum } \\
\text { indicum } \mathrm{L} .\end{array}$ & Til & Leaves & $\begin{array}{l}\text { Kidney } \\
\text { stone }\end{array}$ & Decocction \\
\hline 46 & $\begin{array}{l}\text { Oryza sativa } \\
\text { L. }\end{array}$ & Dhan & Seeds & Leucorrhea & Decocction \\
\hline 47 & $\begin{array}{l}\text { Punica } \\
\text { granatum L. }\end{array}$ & Dalimb & Seeds & Indigetion & Powder \\
\hline 48 & \begin{tabular}{|l} 
Aegle \\
marmelos \\
(L.) Corr.
\end{tabular} & Bel & Fruit & Indigetion & Sharbat \\
\hline 49 & $\begin{array}{l}\text { Mimusops } \\
\text { elengi L. }\end{array}$ & Bakul & Flower & Fever & Powder \\
\hline 50 & $\begin{array}{l}\text { Datura } \\
\text { fastuosa L. }\end{array}$ & Dhotra & Leaves & Asthama & Decocction \\
\hline
\end{tabular}

\section{Discussion:}

Medicinal plants have strong acceptance in spiritual activities of central Indian inhabitant communities, who worshiped the plants in the form of god, goddesses, and minor deities . Due to the unavailability of modern health facilities, poverty, connectivity with urban centre, awareness, etc. people in rural areas are still relying on traditional medicines for their health care. Many communities use wild plant parts for the primary healthcare, due to belief in its effectiveness, easily available, lack of modern medicines. Apart from human use, many plant species were also used in animal husbandary as the primary source of healthcare. United nations University proposal defines traditional knowledge system as "traditional knowledge or „local knowledge is a record of human achievement in comprehending the complexities of life and survival in often unfriendly environments. Traditional knowledge may be technical, social, organizational, or cultural was obtained as part of the great human experiment of survival and development." Traditional knowledge provides the basis for problemsolving strategies for local communities, especially the poor. Diseases are the curse of civilization ever since its advent on this planet. Humans have been struggle against a variety of diseases since ancient periods. Finally humans developed a native system of medicine. For millennia human societies have been depending on forest and forest products like medicinal plants, aromatic plants, edible roots, food and many other things for their livelihoods as well as primary health needs. In certain areas these folk medical prescriptions are widespread and have survived through ages from one generation to the next generation through the word of mouth. They do not exist as on paper knowledge. Normally these systems of medicine depend on old people's experiences and practices.

\section{Conclusion:}

The Vidharbian people have a close relationship with nature. They are fully dependent upon forest for food, fruits, fodder, and medicinal plants for their healthcare. Local people in this region, especially older age people, tribal people and women heavily use these traditionally available medicinal plants for health and believe that these are easily available, less expensive and have no side effects as compare to modern medicine. The present situation of traditional knowledge regarding to medicinal plants everywhere is an issue of deep anxiety as the traditional knowledge is gradually declining and disappearing from the countryside. Due to the deforestation, impact of tourism on natural vegetation of this region, population explosion \& heavily construction of this region for development and changing of climate in Vidharbha region and many more to responsible for its. We have to make proper policies and do implement these to conserve the forests and medicinal plants. Farmers and local people should be involved in the cultivation of medicinal plants at least on their barren and fallow land.

\section{References:}

Nadkarni AK; Indian Materea Medica. Vol. 1 (3rd edn), 1954; Popular Book Depot, Bombay.

Pei SJ; Ethnobotanical approaches of traditional medicine studies: Some experiences from Asia. Pharmaceut. Bio, 2001; 39: 74-79.

Bentley R, Trimen H; Medicinal Plants. Vols-IV (repr. Edn). 1980; International Book Distributor, Dehradun

Kirtikar KR, Basu BD; Indian Medicinal Plants. Vols. 1-4, 1933. Allahabad, India.

Gaur RD; Flora of District Garhwal with ethnobotanical notes, Transmedia Publications, Media House, Srinagar Garhwal, 1999.

Chhetri DR, Basnet D, Chiu PF, Kalikotay S, Chhetri G, Parajuli S; Current status of ethnomedicinal plants in the Darjeeling Himalaya. Curr. Sci, 2005; 89(2): 268-268.

Malla SB, Shakya PR; Medicinal plants of Nepal. In: T.C., 1984. 
Edwards DM; Non Timber Forest Products (NTFPs) form Nepal:Aspects of trade in Medicinal and aromatic plants. FORESC Monograph. Forest Research and Survey Center, Kathmandu, Nepal. 1996.

Pandey HP, Verma BK; Phytoremedial wreath: A traditional excellence of healing. Ind. For, 2005; 131(3): 437-441

Al-Quran S ; Ethnobotanical survey of folk toxic plants in southern part of Jordan. Toxicon, 2005; 46:119-126.

Hanazaki N, Tamashiro JY, Leitao-Filho H, Gegossi A; Diversity of plant uses in two Caicaras communities from the Atlantic forest coast, Brazil. Bio. Conserv, 2000; 9: 597-615.

Rossato SC, Leitao-Filho H, Gegossi A; Ethnobotany of Caicaras of the Atlantic forest coast (Brazil). Econ. Bot, 1999; 53: 387-395.

Azaizeh HS, Fulder K, Khalil, Said O; Ethnomedicinal knowledge of local Arab practitioners in the Middle East Region. Fitoterapia, 2003; 74:98-108.

Silori CS, Badola R; Medicinal plants cultivation and sustainable development: a case study in buffer zone of the Nanda Devi Biosphere Reserve, Western Himalaya, India. Mountain Research and Development, 2000; 20:272-9. 